\title{
CRITERIA RELATED TO PROCESSES OF TEACHERS' SUCCESSFUL PROFESSIONAL DEVELOPMENT AND QUALIFICATION IMPROVEMENT
}

\author{
Migena Alimehmeti, Leonard Danglli \\ University of Tirana, Albania \\ E-mail: migena22001@yahoo.com, leonard_albania@yahoo.com
}

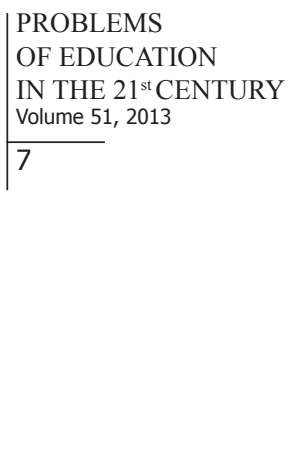

\begin{abstract}
It is necessary for teachers to develop professionally and deal with problem situations. However, that will be done by changing the teaching models, in close cooperation and support by the institutions which are completely specialized in terms of inclusion. In this conceptual context, reforms in the field of teacher professional development in different countries, including Albania, are being implemented. To make this concept as clear as possible, this study makes use of various theoretical sources, such as theoretical attitudes by numerous scholars, conclusions and field studies carried out by different international entities in the field of education, including various publications by EU. To provide an accurate picture of the situation in Albania with regard to this issue, this study refers to data extracted from the regulations of the Albanian Ministry of Education, data from annual reports of the institutions on educational development, as well as data from questionnaires with teachers of different levels and seniority.
\end{abstract}

Key words: long term process, professional development, self-evaluation, teacher skills.

\section{Introduction}

The realization of the educational process requires teacher's dynamic engagement. Before developing a teacher professional development program, a research should be carried out in order to find out the criteria and principles of teacher professional development in Albania and compare them with the guidelines set by EU member states. This research focuses on problems related to skills for career performance and management, as well as professional selfevaluation quality of Albanian teachers. As a result, a questionnaire has been carried out with teachers of primary, middle and secondary schools in four major cities of Albania.

Various publications by European organizations (OECD, Teachers Professional Development 2010) and Albanian educational institutions (MASH, ministry of Education in Albania and IZHA, the Institute for educational development) have been analyzed. The main conclusions show that teacher professional development in Albania is absorbing the criteria set by EU, whose member Albania aims to become in the future. Nevertheless, there are aspects which are either minimally or not at all influenced by these criteria, particularly with regard to planning continuous professional development, access to data on national and international programs, labor market and the future challenges for the teacher.

\section{Problems of Research}

The education system plays an important role in achieving the European Union's goals for economic growth, social cohesion and environmental sustainability. The European Union supports the organization of education in two ways:

- by assisting individual teachers to undertake professional development activities;

- by bringing policy makers from Member States to promote good practice. 
PROBLEMS

OF EDUCATION

IN THE $21^{\text {st }}$ CENTURY

Volume 51, 2013

The Council and the Parliament have adopted various recommendations: "Improving Quality Evaluation in School Education" (2001/166./EC;OJ L60 of 1.3.2001), "Promoting Key Competencies for lifelong Learning" (2006/962/EC; OJ L394/10 of 30.12.2006). The Education Council has adopted conclusions: "Improving the Efficiency and Equity of Education and Training Systems" (OJ 2006/C 298/03 of 8.12.2006), "Improving the Quality of teacher Education" (2007/C 300/07 of 15.11.2007).

The EU Ministers of Education have committed themselves to a far-reaching agenda for developing policies on teacher education. These policies are organized around these directions: policies for greater incentives for teachers to update their skills throughout their professional lives; policies for efforts to ensure that in-service education is responsive to teaching needs in terms of both quality and quantity. Moreover, Members States have agreed to work on the following areas of teacher education policy (Progress towards the Lisbon objectives in education and training. Indicators and benchmarks, 2009):

- A continuum of teacher education, which means that provision for teachers' initial education, early career support and further professional development are co-ordinate and coherent.

- Professional values in which teachers are encouraged to be reflective practitioners, to be autonomous in their professional development and to do research.

- Regarding teaching as an attractive profession to ensure the recruitment of new teachers.

- Ensuring qualification for teachers so that there is a suitable balance between research-based studies and teaching practice.

- Ensuring that teachers have access to effective early career support programs.

- Ensuring teachers with leadership functions.

In Albania, teacher professional development aims at encouraging pre-university education teachers (primary, 9-year education and High school) to be part of the professional development process at school, area, region and local level. This teacher professional development should be based on clear professional competences and should reflect changes in official curricula and teaching methods (IKT, 2008)

Professional competencies include the system of knowledge, skills and attitudes that are necessary to successfully solve a teaching situation of a certain level. Professional development is a continuous process that cannot be limited to a qualification process or participation in a test. This process is viewed as a combination of the individual efforts of the teacher by making use of professional support provided at school, region and national level (IKT, 2009, 2010).

Under the directive of the Ministry of Education and Science of Albania no. 2, dated 2012, the qualification of pre-university teachers for 2012 is carried out through the personal professional development portfolio and the relevant exams.

Exams are organized on the basis of qualification programs and curricula for teachers in pre-school, primary and secondary. The Minister's directive defines the subject in which the teacher will take the test.

The personal professional portfolio of the teacher must necessarily include an annual plan for the subject he/she teaches, a model test for one of the chapters of the subject, objectives and learning outcomes for a chapter, a detailed lesson plan, including the methods for meeting the objectives of the lesson, as well as a plan of curricular program (IKT, 2011). The portfolio should also include other additional documents concerning personal qualification description, such as Curriculum Vitae, copies of the training certificates with credits, copies of scientific degrees, certificates of foreign languages and Information and Communication Technology. This portfolio is evaluated by a system of points by the relevant state institutions such as DAR and ZA. The candidate who does not get the minimal points for the portfolio is not allowed to take the qualification test.

The classification of the candidates into the relevant category is based on the final results and it is reflected in salary rise. 
Migena ALIMEHMETI, Leonard DANGLLI. Criteria Related to Processes of Teachers' Successful Professional Development and Qualification Improvement

- 5 to 9 years for the third category of qualification;

- 10 to 19 years for the second category of qualification;

- Over 20 years for the first category of qualification.

The evaluation for teacher qualification can be summarized as follows:

- Points of the portfolio.

- Points of the first part of the test.

- Points of the second part of the test.

- Extra points.

The tests cover the following aspects:

- General preparation of the candidate, including mastery and understanding of syllabus contents and responsibility for meeting the requirements of school documentation.

- Mastery of teaching methodology aspects of the subject.

- Mastery of concepts and scientific theories treated in the school curriculum and texts.

The qualified candidate is awarded the certificate, which contains the evaluation in letter and word. This way of management ensures teachers professional development in both knowledge content and pedagogical content of the lesson.

\section{Research Focus}

This study focuses on the comparison between European experience and the Albanian one in terms of teacher professional development mechanism.

It must be pointed out that in Albania, based on the procedure elaborated above, teachers' work consists of two components: scientific and pedagogical aspects. Therefore, for successful teaching, special scientific knowledge of designated areas and pedagogical knowledge, abilities and skills are needed, and professional teacher development in Albania aims to be a continuum and co-ordinate process, by encouraging teachers to be autonomous in their professional development and focus on self-evaluation.

Considering the practice pursued in Albania, the criteria and guidelines of the EU about teacher professional development do not appear in an explicit way, such as the early career support, the encouragement for teachers to be reflective practitioners, ensuring the recruitment of new teachers, ensuring the qualification for teachers to achieve a suitable balance between research and teaching practice, ensuring teachers to have access to career support programs.

\section{Methodology of Research}

\section{General Background of Research}

Career development is the aspect of human development that includes the way individuals incorporate their values about work, their abilities and decisions about education (Herr, 2004). This process must be based on well defined principles and criteria, which result from continuous scientific studies and experience (OECD, 2010, Lisbon objectives in education and training, 2009, Career Education: Glossary, 2010).

The teacher professional development is considered broader than staff development, the provision of organized in service programs designed to foster the growth of groups of teachers, and career development, as the growth which occurs as the teacher moves through the professional career cycle (Reimers, 2003).

There are no studies in Albania to link together the teachers' concepts, identity and curricular experience in professional teacher development. Therefore, the best way to see how 
PROBLEMS

OF EDUCATION

IN THE $21^{\text {st }}$ CENTURY

Volume 51, 2013

these concepts are related to professional development of Albanian teachers is just by interviewing them.

\section{Sample of Research}

To better understand the situation of teacher professional development in Albania and see how it compares to the concepts and principles set by EU concerning this issue, two questionnaires were designed. These questionnaires were answered by teachers of primary education, middle education and secondary education, divided in three categories. Teachers of the first category have over 20 years of work experience, (108 teachers), those of the second category have 10 to 19 years of work experience ( 81 teachers), and the teachers of the third category have 5 to 9 years of experience ( 31 teachers). The teachers who answered the questionnaire work in the following schools: Fan Noli, Cajupi, Petro Nini Luarasi and Naim Frasheri, in four cities in Albania su as Tirana, Durres, Berat and Korçe.

\section{Instrument and Procedures}

The questionnaire questions were closed-ended questions so as to make it easier to collect and process the outcomes data. This method enables collecting answers about many topics in a short period of time and it provides access to a great number of teachers.

The questionnaires were completed by the teachers in classrooms where the authors of this study were present. In terms of the time allowed, they were given all the time needed. This particular method was chosen as a very effective one for the collective administration of the questionnaires, which makes it possible to avoid outside influence on individual answers and to remove any doubts the respondents might have concerning certain questions. The questionnaire was conducted in December 2012 and it was completed by 220 teachers.

It must be highlighted that the data collected through the questionnaire have a quantitative nature.

The data have been gathered and shown in separate tables, which have made it possible to offer an interpretation of the results yielded.

\section{Data Analysis}

To enter the data the first step was creating classification tables in which different categories of possible answers were grouped. And since the questionnaire was neither digital nor electronic the data was entered manually. To minimize human errors in this process, all the data analyzed were first entered into the tables printed on paper and then into the computer. Both data transfer processes were double-checked to continue with calculating the percentage of the given answers. The descriptive method and the frequency analysis were used for the two tables. The issues of this questionnaire are related to the EU principles of teacher professional development, under two viewpoints: the first questionnaire focuses on career and management performance, whereas the second one covers the self-evaluation of teacher professional qualities. The questionnaire items refer to work inside the school, including team work, participation in activities and projects, lesson preparation, communication and experience exchange, studies, individual development, communication with parents and different organizations, continuous education and specialization. The teachers had to choose between two possible replies, Yes or NO. Only the positive replies of the respective questions are analyzed and provided in the table by percentage.

\section{Results of Research}

The description of the procedure of pre-university system teacher qualification followed by Albania does not allow us to clearly define the orientation towards the criteria and principles set by member States in their teacher professional development policies. The Albanian experi- 
ence is mainly an individual process. The questionnaire helped us obtain information to see

PROBLEMS

OF EDUCATION

IN THE $21^{\text {st }}$ CENTURY

Volume 51, 2013

how they relate to the European conception of their professional development.

As regards continuous professional development, encouragement of autonomy in teachers, provision of qualification to balance research and practice, access to career development programs, it results that the Albanian teachers of the third category, with less work experience ( 5 to 9 years of experience) give a lower percentage (59\%), compared to the first category (over 20 years of experience) (66\%) and the second category (10 to19 years of experience) $93 \%$. This category also shows lower percentage compared to the two other categories with regard to knowledge of criteria for professional development (55\%), continuous preparation and qualification and professional training (41\%), their information about the labor market at the beginning of their career (36\%), the use of computer programs for professional development (32\%), their preparation to accomplish interdisciplinary relations between various topics $(39 \%)$, coordination of the school personnel and the community to provide as many sources of information as possible (3.6\%), the modern practice of assisting colleagues in their teaching process $(2.3 \%)$, as well as reflections on applying original teaching models (29\%).

However, this category of teachers is better at the following areas: the ability to communicate and work in a team (98\%), the ability to use critical and analytical thinking to resolve problems (96\%), self-criticism and self-evaluation (99\%), the ability to manage self-preparation, planning and self-control time (100\%), as well as accepting suggestions about their performance on the part of their instructors and specialists of the relevant institutions $(100 \%)$.

Less satisfactory results are also observed in the positive replies by the teachers of the first category who have over 20 years of work experience. Regarding information about the labor market and information sources it is $(11.6 \%)$, the use of computer programs for professional development $(17 \%)$, the adequacy of training programs $(42 \%)$, the interdisciplinary relations between different topics (31\%), coordination of school personnel and the community $(32 \%)$, assisting other teachers/colleagues to improve teaching methodology (10\%). these responses show that it is necessary to work towards the adoption of this category with contemporary requirements.

This category is better at aspects concerning the ability to cooperate in a group (78\%), knowledge of criteria for professional development (81\%), continuous preparation and qualification and professional training (74\%), organizational and managerial abilities $(85.6 \%)$, the ability to think analytically and critically to resolve problems $(88.3 \%)$, ability to manage time for self-preparation and planning (96\%), knowledge of methods of the disciplines they teach $(84.5 \%)$, accepting suggestions about their performance on the part of inspectors (92\%), reflections to experiment original teaching models $(81 \%)$.

Teachers of the second category have a better result in their replies compared to the first and third group. However, they show a relatively low percentage in using computer programs for professional development $(20 \%)$, adequacy of training programs $(36 \%)$, interdisciplinary relations between different topics $(42 \%)$, coordination of school personnel and the community to provide as many sources of information as possible (28\%), assisting teachers to improve teaching methodology $(6.3 \%)$. 
PROBLEMS

OF EDUCATION

IN THE $21^{\text {st }}$ CENTURY

Volume 51,2013

Table 1. Skills for career performance and management.

\begin{tabular}{|c|c|c|c|c|c|c|c|c|c|}
\hline & \multicolumn{3}{|c|}{$\begin{array}{l}\text { Category I } \\
\text { Over } 20 \text { years of experience }\end{array}$} & \multicolumn{3}{|c|}{$\begin{array}{l}\text { Category II } \\
10-19 \text { years of experience }\end{array}$} & \multicolumn{3}{|c|}{$\begin{array}{l}\text { Category III } \\
5-9 \text { years of experience }\end{array}$} \\
\hline & primary & $\begin{array}{l}\text { 9-year } \\
\text { educa- } \\
\text { tion }\end{array}$ & $\begin{array}{l}\text { High } \\
\text { school }\end{array}$ & primary & $\begin{array}{l}\text { 9-year } \\
\text { educa- } \\
\text { tion }\end{array}$ & $\begin{array}{l}\text { High } \\
\text { school }\end{array}$ & primary & $\begin{array}{l}\text { 9-year } \\
\text { educa- } \\
\text { tion } \\
\end{array}$ & $\begin{array}{l}\text { High } \\
\text { school }\end{array}$ \\
\hline $\begin{array}{l}\text { Skills for career } \\
\text { performance and } \\
\text { management }\end{array}$ & $\begin{array}{l}6 \text { teach- } \\
\text { ers }\end{array}$ & $\begin{array}{l}58 \\
\text { teachers }\end{array}$ & \begin{tabular}{|l|}
44 \\
teach- \\
ers
\end{tabular} & 4 teacher & $\begin{array}{l}44 \\
\text { teachers }\end{array}$ & $\begin{array}{l}33 \\
\text { teachers }\end{array}$ & $\begin{array}{l}2 \text { teach- } \\
\text { ers }\end{array}$ & $\begin{array}{l}18 \text { teach- } \\
\text { ers }\end{array}$ & $\begin{array}{l}11 \\
\text { teach- } \\
\text { ers }\end{array}$ \\
\hline \multirow{2}{*}{$\begin{array}{l}1.1 \text { Ability to } \\
\text { cooperate in a } \\
\text { group (\%) }\end{array}$} & 67 & 85 & 82 & 100 & 95 & 97 & 100 & 94 & 98 \\
\hline & \multicolumn{3}{|c|}{53} & \multicolumn{3}{|c|}{97} & \multicolumn{3}{|c|}{97} \\
\hline \multirow{2}{*}{$\begin{array}{l}1.2 \text { Abilities for } \\
\text { lifelong career } \\
\text { development (\%) }\end{array}$} & 33 & 83 & 82 & 98 & 94 & 88 & 50 & 62 & 66 \\
\hline & \multicolumn{3}{|c|}{66} & \multicolumn{3}{|c|}{93} & \multicolumn{3}{|c|}{59} \\
\hline \multirow{2}{*}{$\begin{array}{l}1.3 \text { Knowledge } \\
\text { of professional } \\
\text { development } \\
\text { criteria }(\%)\end{array}$} & 83 & 74 & 88 & 70 & 87 & 71 & 50 & 56 & 61 \\
\hline & \multicolumn{3}{|c|}{81} & \multicolumn{3}{|c|}{76} & \multicolumn{3}{|c|}{55.6} \\
\hline \multirow{2}{*}{$\begin{array}{l}1.4 \text { Continuous } \\
\text { preparation and } \\
\text { qualification as } \\
\text { well as profes- } \\
\text { sional training } \\
(\%)\end{array}$} & 50 & 86 & 86 & 75 & 97 & 93 & 0 & 58 & 66 \\
\hline & \multicolumn{3}{|c|}{74} & \multicolumn{3}{|c|}{88} & \multicolumn{3}{|c|}{41} \\
\hline \multirow{2}{*}{$\begin{array}{l}1.5 \text { Organizational } \\
\text { and managerial } \\
\text { skills (\%) }\end{array}$} & 83 & 84 & 90 & 75 & 98 & 69 & 100 & 95 & 97 \\
\hline & \multicolumn{3}{|c|}{85.6} & \multicolumn{3}{|c|}{80} & \multicolumn{3}{|c|}{97} \\
\hline \multirow{2}{*}{$\begin{array}{l}1.6 \text { Knowledge } \\
\text { of the labor mar- } \\
\text { ket and sources } \\
\text { of information } \\
(\%)\end{array}$} & 0 & 12 & 23 & 75 & 67 & 72 & 0 & 57 & 53 \\
\hline & \multicolumn{3}{|c|}{11.6} & \multicolumn{3}{|c|}{71} & \multicolumn{3}{|c|}{36.6} \\
\hline \multirow{2}{*}{$\begin{array}{l}1.7 \text { Use of com- } \\
\text { puter programs } \\
\text { for professional } \\
\text { development }(\%)\end{array}$} & 17 & 19 & 15 & 21 & 18 & 22 & 50 & 20 & 27 \\
\hline & \multicolumn{3}{|c|}{13.6} & \multicolumn{3}{|c|}{20} & \multicolumn{3}{|c|}{32} \\
\hline \multirow{2}{*}{$\begin{array}{l}\text { 1.8 Professional } \\
\text { development } \\
\text { encouraged by } \\
\text { leading institu- } \\
\text { tions }(\%)\end{array}$} & 81 & 77 & 65 & 96 & 93 & 75 & 100 & 94 & 97 \\
\hline & \multicolumn{3}{|c|}{74} & \multicolumn{3}{|c|}{88} & & 97 & \\
\hline 1.9 Adequacy & 55 & 38 & 33 & 48 & 27 & 34 & 0 & 17 & 11 \\
\hline $\begin{array}{l}\text { of training pro- } \\
\text { grams (\%) }\end{array}$ & & 42 & & 36 & & & 9.3 & & \\
\hline
\end{tabular}


Migena ALIMEHMETI, Leonard DANGLLI. Criteria Related to Processes of Teachers' Successful Professional Development and Qualification Improvement

Table 2. My professional self-evaluation quality.

PROBLEMS

OF EDUCATION

IN THE $21^{\text {st }}$ CENTURY

Volume 51, 2013

\begin{tabular}{|c|c|c|c|c|c|c|c|c|c|c|}
\hline \multirow{3}{*}{\begin{tabular}{|l|} 
\\
\\
$2 \quad M y$ \\
$\begin{array}{l}\text { professional } \\
\text { self-evaluation } \\
\text { quality }\end{array}$ \\
\end{tabular}} & \multicolumn{3}{|c|}{$\begin{array}{l}\text { Category I } \\
\text { Over } 20 \text { years of experience }\end{array}$} & \multicolumn{3}{|c|}{$\begin{array}{l}\text { Category II } \\
10-19 \text { years of experience }\end{array}$} & \multicolumn{4}{|c|}{$\begin{array}{l}\text { Category III } \\
5-9 \text { years of experience }\end{array}$} \\
\hline & \multirow{2}{*}{$\begin{array}{l}\text { primary } \\
6 \text { teach- } \\
\text { ers }\end{array}$} & \multirow{2}{*}{$\begin{array}{l}\text { 9-year } \\
\text { educa- } \\
\text { tion } \\
58 \text { teach- } \\
\text { ers }\end{array}$} & \multirow{2}{*}{$\begin{array}{l}\text { High } \\
\text { school } \\
44 \text { teach- } \\
\text { ers }\end{array}$} & \multirow{2}{*}{\begin{tabular}{|l|} 
primary \\
4 \\
teacher
\end{tabular}} & \multirow{2}{*}{$\begin{array}{l}\text { 9-year } \\
\text { educa- } \\
\text { tion }\end{array}$} & \multirow{2}{*}{\begin{tabular}{|l} 
High \\
school
\end{tabular}} & \multirow{2}{*}{\begin{tabular}{|l} 
primary \\
2 \\
teach- \\
ers
\end{tabular}} & \multicolumn{2}{|c|}{$\begin{array}{l}\text { 9-year } \\
\text { education }\end{array}$} & \multirow{2}{*}{$\begin{array}{l}\text { High } \\
\text { school } \\
\text { chers }\end{array}$} \\
\hline & & & & & & & & $\begin{array}{l}18 \\
\text { teach- } \\
\text { ers }\end{array}$ & $\begin{array}{l}11 \\
\text { tea }\end{array}$ & \\
\hline \multirow{2}{*}{$\begin{array}{l}2.1 \text { Analytical } \\
\text { and critical } \\
\text { thinking to } \\
\text { resolve prob- } \\
\text { lems }(\%)\end{array}$} & 83 & 93 & 89 & 100 & 98 & 100 & 100 & 92 & 98 & \\
\hline & \multicolumn{3}{|c|}{88} & \multicolumn{3}{|c|}{99} & \multicolumn{4}{|c|}{96.6} \\
\hline \multirow{2}{*}{$\begin{array}{l}2.2 \text { Self-crit- } \\
\text { icism, self- } \\
\text { evaluation } \\
\text { and efforts to } \\
\text { improve qual- } \\
\text { ity }(\%)\end{array}$} & 33 & 52 & 91 & 100 & 98 & 91 & 100 & 98 & 10 & \\
\hline & \multicolumn{3}{|c|}{58.6} & \multicolumn{3}{|c|}{96} & \multicolumn{4}{|c|}{99} \\
\hline \multirow{2}{*}{$\begin{array}{l}2.3 \text { Ability to } \\
\text { manage time. } \\
\text { Self-prepara- } \\
\text { tion, planning } \\
\text { and self-con- } \\
\text { trol }(\%)\end{array}$} & 100 & 93 & 95 & 100 & 100 & 95 & 100 & 100 & 10 & \\
\hline & & 96 & & & 98 & & & 100 & & \\
\hline \multirow{2}{*}{$\begin{array}{l}2.4 \text { Knowledge } \\
\text { of content and } \\
\text { methods of the } \\
\text { relevant educa- } \\
\text { tional field }(\%)\end{array}$} & 73 & 83 & 97 & 50 & 77 & 82 & 50 & 68 & 59 & \\
\hline & & 84 & & & 69.6 & & & 59 & & \\
\hline \multirow{2}{*}{$\begin{array}{l}2.5 \text { Interdisci- } \\
\text { plinary rela- } \\
\text { tions between } \\
\text { different topics } \\
(\%)\end{array}$} & 33 & 28 & 33 & 25 & 48 & 53 & 100 & 12 & 7 & \\
\hline & & 21 & & & 42 & & & 39.6 & & \\
\hline \multirow[b]{2}{*}{$\begin{array}{l}2.6 \text { coordina- } \\
\text { tion of school } \\
\text { personnel and } \\
\text { the community } \\
\text { to provide as } \\
\text { many sources } \\
\text { of information } \\
\text { as possible } \\
(\%)\end{array}$} & 17 & 42 & 37 & 25 & 23 & 36 & 0 & 4 & 7 & \\
\hline & & 32 & & & 28 & & & 3.6 & & \\
\hline \multirow[b]{2}{*}{$\begin{array}{l}\text { 2.7 Assisting } \\
\text { teachers/col- } \\
\text { leagues to im- } \\
\text { prove teaching } \\
\text { methodology } \\
\text { and overcome } \\
\text { teaching dif- } \\
\text { ficulties (\%) }\end{array}$} & 17 & 5 & 9 & 0 & 14 & 5 & 0 & 5 & 2 & \\
\hline & \multicolumn{3}{|c|}{10} & \multicolumn{3}{|c|}{6} & \multicolumn{4}{|c|}{2.3} \\
\hline
\end{tabular}


PROBLEMS

OF EDUCATION

IN THE $21^{\text {st }}$ CENTURY

Volume 51, 2013

\begin{tabular}{|c|c|c|c|c|c|c|c|c|c|}
\hline \multirow[b]{2}{*}{$\begin{array}{l}2.8 \text { Accept- } \\
\text { ing sugges- } \\
\text { tions about } \\
\text { personal } \\
\text { performance } \\
\text { by instructors } \\
\text { and specialists } \\
\text { of relevant } \\
\text { institutions } \\
\text { (\%) }\end{array}$} & 83 & 98 & 95 & 100 & 100 & 100 & 100 & 100 & 100 \\
\hline & \multicolumn{3}{|c|}{92} & \multicolumn{3}{|c|}{100} & \multicolumn{3}{|c|}{100} \\
\hline \multirow{2}{*}{$\begin{array}{l}2.9 \text { Reflection } \\
\text { on original } \\
\text { teaching mod- } \\
\text { els (\%) }\end{array}$} & 100 & 78 & 65 & 72 & 89 & 93 & 0 & 54 & 33 \\
\hline & \multicolumn{3}{|c|}{81} & \multicolumn{3}{|c|}{84.6} & \multicolumn{3}{|c|}{29} \\
\hline
\end{tabular}

The results of the questionnaire show that:

- Teachers of the three categories, classified by seniority, are willing to work in a team.

- As regards knowledge of lifelong career development, the response of the young teachers is at a lower percentage (59\%). The same fact is observed in the response of the following question. This makes us believe that they lack sufficient information.

- Moreover, there are a relatively low percentage of responses by the teachers of the three categories concerning knowledge of professional developing process, labor market information, computer application, and sufficiency of training programs.

It is noticed that the responses of the teachers with regard to interdisciplinary correlation between different subject contents, about the coordination of school and community personnel, about teacher cooperation in improving teaching methodologies, are at an unsatisfactory level.

\section{Discussion}

According to English Dictionary for Advancer Learners (2001) and Le petit Robert (2004), the teacher is a person who teaches, or is in charge of teaching, usually as a job at a school or similar institution, in a teaching staff, and teaching means giving somebody instructions so that they know about it or how to do it. As far as the process of teaching is concerned, these dictionaries define it as learning the way to react/behave and think; an action or art of teaching, conveying knowledge to the learner. Therefore, the teacher, or rather the profession of the teacher, must always be up-to-date so that it is in line with social or scientific developments, which are continuous.

CDG (Career Development Guidelines, Carl D. Perkins Career and Technical Education Act of 2006) considers professional teacher development a mainly personal process. To achieve success, the teacher must develop skills related to interaction with others, understand and use career information, how to make decisions, how to make career plans. The teacher should also have knowledge of the self concept, how to follow and adapt to the progress of the society, etc.

According to the TALIS survey (TALIS survey provides information on the form, content and contextual conditions of teacher professional development in 24 countries. OECD, 2010), "the professional development is defined as activities that develop an individual's skills, knowledge, expertise and other characteristics as a teacher". Teachers' professional development is treated in the context of educational quality and regards professional development as an instrumental learning and educational achievement. The TALIS survey distinguishes individual and collective professional development and endorses the theory of professional learning communities as a context for continuous professional development. There are indications that schools which promote educational change show better results in terms of student preparation. 
EU policies on teachers' professional development take a broad perspective and regard teacher professional development as an instrument to support the quality of educational outcomes and as a means to ensure that education remains responsive to developments in society. The content of the TALIS survey shows the broad extending of the perspective by giving aspects of professional development. Diverse qualification programs are included with the more continuous forms that are embedded in the day-to-day work of the teachers. Content areas in which teachers express development needs include aspects of teaching and of school management and administration. It must be underlined that qualification programs focus more on teaching. Prioritizing both aspects of teachers' professional development might be a deliberate policy choice.

Based on the EU experience, the qualification procedures in Albania and the results of the questionnaire, it is important to highlight the following:

- The bodies in charge of professional training and qualification of teachers in Albania should place more emphasis on training that contributes to gaining professional competencies required in teacher qualification programs.

- Young teachers, those with less experience in this profession, should be encouraged and involved in more training or cooperation programs so that they are part of continuous training and improve their professional skills.

- Cooperation with universities preparing future teachers should be enhanced with a view to further improving the teacher education curricula so that they are in conformity with labour market requirements and social development.

- Training in teaching methodology should be encouraged as it is one of the areas where teachers show lower scores.

- Exchange of experience between teachers of the same or different categories should be encouraged.

- Production of source materials that facilitate qualification, such as guides and manuals, should be encouraged too.

The profession of the teacher, which includes the principles and criteria of professional teacher development, can be presented as follows: (Haloçi, 2010):

- Knowledge on policies.

- Knowledge about social progress and recruitment policies.

- Knowledge and use of didactic and technological means.

- Flexibility and willingness to lifelong learning.

- Knowledge and attitudes to the mission.

- Up-to-date academic knowledge about the subject.

- Didactic, pedagogical and up-to-date knowledge.

The competences and skills to be acquired by a teacher since the beginning of his/her career must be diverse. This does not imply that they should be acquired separately but combined both horizontally (simultaneously) and vertically (chronologically). They include knowledge of the subject they teach, open-mindedness, favorable attitude to learning as a continuous and self-directed process, creativity, cooperation, good communication skills with students, parents and staff, ability to work in a team, ability to manage "risks', taking initiatives, etc.

Studies published by EU show that research on continuous professional development of teachers is fragmentary. Because of this reason and the individual experience of each country, it is impossible to have a common model for different qualification levels. More research is needed to study the characteristics of this process so that various methods are designed, sources are used and long-term plans are set up. 


\section{PROBLEMS \\ OF EDUCATION \\ IN THE $21^{\text {st }}$ CENTURY \\ Volume 51,2013 \\ 16 Conclusions}

Professional development has become very important nowadays and is in line with the changes in technology, globalization, and knowledge-based society. Most importantly, professional development is now being recognized as a lifelong process.

This process seems to be influenced by individual factors, i.e. psychological ones, such as career motivation, self-evaluation, self-efficacy and being more autonomous. A teacher should constantly develop academically and professionally and he/she should know to initiate, clarify, contribute, supervise and react. One of the main objectives of their continuous qualification programs should consist in enhancing or maintaining motivation, enhancing the commitment to a continuous learning or professional development process.

The initial teacher education cannot provide the teacher with the knowledge and skills necessary for the lifelong teaching career. Teachers need to acquire new knowledge and skills and develop them continuously so that to keep up with the changing labour market.

Teaching is much more than giving knowledge. It involves classroom management, lesson preparation, and organization of teaching and learning activities, creating and maintaining a certain atmosphere, evaluation and feedback.

Albania, as a country in the process of development and which aims at its integration in the EU, should avoid some gaps observed related to the professional development of teachers. Albania should regularly publish information on the labour market so that teachers could draw up their plans associated with this profession. Also, employment and continuing professional development criteria should be predetermined at the time of recruitment of new teachers. Another disadvantage, which is reflected in the low response of all categories, is related to the use of computer programs for professional development. Governmental institutions, that deal directly with the teacher professional development programs, should make available to the teacher computer programs for professional development and provide direct access to them. The teachers of the three categories claim about the insufficiency of training programs. This indicates that they are motivated to work in this profession and to continue their professional development and this fact should be supported by the Albanian's educational institutions.

\section{References}

Dictionnaire de didactique du français langue étrangère et seconde. ASDIFL (2003). Coordoné par JeanPierre Cuq. CLE International, S.E.J.E.R. Paris.

Haloçi, A. (2010). Les competences professionnelles d'un enseignant de langues. Monographie. Redona Publishing. Tirane.

Herr, E. (2004). Career guidance and counseling through the lifespan: systematic approaches. $6^{\text {th }}$ ed. Boston; London: Pearson.

IKT (2008). Studim, ç’ndryshim solli kualifikimi i mesuesve 2008. Studim. Teste. Tirane.

IKT (2009). Studim, ç'ndryshim solli kualifikimi i mesuesve 2009. Studim. Teste. Tirane.

IKT (2010). Studim, ç’ndryshim solli kualifikimi i mesuesve 2010. Studim. Teste. Tirane.

IKT (2011). Studim, ç’ndryshim solli kualifikimi i mesuesve 2011. Studim. Teste. Tirane.

OECD (2010). Teachers' Professional Development. Europe in international comparison. Analysis of teachers' professional development based on the OECD's Teaching and Learning International Survey (TALIS). Education and culture DG. European Union. Luxembourg.

Perkins, C. (2006). Career and Technical Education. Career Development Guidelines. Retrieved 11.01. 2013, from cte,ed.gov/acrn/ncdg/what.htm.

Progress towards the Lisbon objectives in education and training. Indicators and benchmarks. (2009). This publication is based on document SEC (2009)1616.

Reimers, E. V. (2003). Teacher professional development an international review of the literature. UNESCO: International Institute for Educational Planning.

Udhezimi i Ministrise se Arsimit dhe Shkences. Nr 2, date 20. 01. 2012. 
Migena ALIMEHMETI, Leonard DANGLLI. Criteria Related to Processes of Teachers' Successful Professional Development and Qualification Improvement

$$
\text { Advised by Mimoza Gjokutaj, University of Tirana, Albania } \mid \begin{aligned}
& \text { PROBLEMS } \\
& \text { OF EDUCATION } \\
& \text { IN THE 21, } 1^{\text {st }} \text { CENTURY } \\
& \text { Volume 51, 2013 } \\
&
\end{aligned}
$$

Received: January 13, 2013

Accepted: March 02, 2013

Migena Alimehmeti

PhD, Lecturer in Teaching Methodology, Teaching Technology, Didactics, Faculty of Foreign Languages, University of Tirana, Rr. Elbasanti, Tirana, Albania.

E-mail: migena22001@yahoo.com

Leonard Danglli

PhD, Teaching Methodology, Teaching Technology, Academic Writing, Faculty of Foreign Languages, University of Tirana, Rr. Elbasanti, Tirana, Albania.

E-mail: leonard_albania@yahoo.com 